UCRL-CR-130632

S/C - B338667

\title{
Low-Jitter Sonoluminescence Cell
}

T. J. Matula

January 1998 


\section{DISCLAIMER}

This document was prepared as an account of work sponsored by an agency of the United States Government. Neither the United States Government nor the University of California nor any of their employees, makes any warranty, express or implied, or assumes any legal liability or responsibility for the accuracy, completeness, or usefulness of any information, apparatus, product, or process

disclosed, or represents that its use would not infringe privately owned rights. Reference herein to any specific commercial product, process, or service by trade name, trademark, manufacturer, or otherwise, does not necessarily constitute or imply its endorsement, recommendation, or favoring by the United States Government or the University of California. The views and opinions of authors expressed herein do not necessarily state or reflect those of the United States Government or the University of California, and shall not be used for advertising or product endorsement purposes. 


\title{
LOW-JTTTER SONOLUMINESCENCE CELL
}

Thomas J. Matula, Ph.D Applied Physics Laboratory University of Washington 1013 NE 40th St.

Seattle WA 98105

January 1998

Final Report

Subcontract No. B338667

1January 1996 - 31 December 1997

\author{
Prepared for: University of California \\ Lawrence Livermore National Laboratory \\ PO Box 808 \\ 7000 East Avenue \\ Livermore, CA 94551
}




\section{Table of Contents}

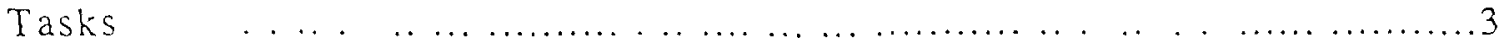

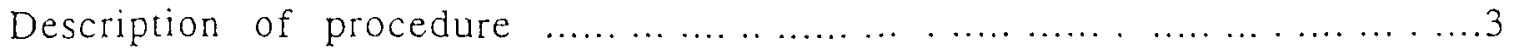

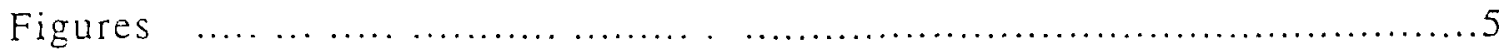


1. This report constitutes the final report for subcontract B338667. The statement of work for this subcontract was divided into three tasks:

\section{TASKS}

Task 1: Produce and quantify the stability of a sonoluminescence cell. The quantification will entail measuring the variation of the amplitude of the light flashes, here called events, and the variation in the time between the individual events i.e., the jitter. On a best effort basis we desire the light amplitude to be stable within 20 So and the jitter between events should be less than 100 ps on average over a period of at least an hour.

Task 2: The quantified cell, which provides the stability and jitter characteristics described above, must be arranged so that it has an optical quality viewing access. The optical properties will enable us to use laser measurement techniques to perform optical probing.

Task 3: There will be a brief informal report on the production of the cell and how it was quantified. This report need only be sufficient to allow the reproduction of the cell at LLNL.

\section{PROCEDURE}

These tasks were accomplished with Dr. Matula working at his laboratory at the University of Washington, and Dustin Froula, working at Lawrence Livermore National Laboratory Levitation cells of various geometries and configurations were built and tested. In all cases, the general procedure was to mount piezoceramic (PZT) transducers to the outside of the cell, using epoxy. No particular type of epoxy appeared to be better than other types. However, as epoxy can dissolve in water, one must take care that the cell is not immersed in water for any length of time.

Since otherwise similar cells can respond differently, each cell required testing. The mechanism for the differences observed may be due to differences in coupling between the transducer and the cell, or in the slight variations in the glass between different cells. Thus, no two cells are equal in response or observed tendencies. Each cell is unique.

Attaching electrical connections to the PZT's involved soldering the leads from RG174-U to the PZT. Although the manufacturer recommends special solder, consisting of $2 \%$ silver, this is not necessary. One must be careful, however, to make sure the silver plating on the ceramic does not lift from the ceramic during the soldering process. One can accomplish this by soldering the wires to the PZT using low heat, flux, and removing the hot iron quickly after the solder is melted. The procedure is as follows:

'Strip each lead of the RG174-U to approximately 1 inch Flatten the leads and dip each into flux paste. Position the flattened ground lead on the outside edge of the PZT. Touch the soldering iron to the lead and apply a small amount of solder. Remove the hot iron after about 5 seconds. Let cool, and wipe away any remaining flux paste. Repeat with the other lead, attaching this lead to the inside edge of the PZT. With the ground lead attached to the outside portion of the PZT, there is a small chance of receiving a shock when the transducer is touched (Note: When storing, attach a ground clip to the PZT on both sides so charges do not build up and cause a shock).

After the PZT leads are cool and cleaned, the PZT is attached to the cell using 5-minute epoxy. A small bead of well-mixed epoxy is formed along the edge of the PZT. The 
levitation cell is then positioned onto the PZT transducer and stabilized with clamps After approximately 1 hour, the cell is ready to be tested.

Several cells were built and tested for stability, in a couple of different configurations. Spherical cells, $125 \mathrm{ml}$, were purchased and piezoceramic transducers (Channel Industries, model (5400) were used to excite standing waves within the cells. In one configuration, two hollow cylindrical transducers (approximately $1 / 2$ inch od, $1 / 2$ inch length, and 1/8 inch wall) were mounted on opposite sides of the cell and connected in parallel. The transducers were driven by a function generator ( $1 \mathrm{~Hz}$ resolution, minimum) and power amplificr. In a sccond configuration, a single large hollow cylindrical transducer ( 1.5 inch od, 1.5 inch long, 1/4 inch wall) was mounted to the bottom of the cell. Both methods produced good results, however, the two-PZT configuration typically requires a matching network in order to supply enough power to generate stable SBSL (figure 1 illustrates the two different configurations). A schematic diagram of the system is shown in figure 2. Note that good jitter results sometimes require building and testing several cells.

The stability of the light emission from the sonoluminescence bubble was monitored with a SR 620 time interval counter. This unit provided us with jitter measurements. In the best cases, we found a jitter of approximately $100-200 \mathrm{ps,} \mathrm{with} \mathrm{a} \mathrm{typical} \mathrm{jitter} \mathrm{of} \mathrm{less} \mathrm{than} 500$ ps for most cells and configurations. The amplitude stability of the light flashes was determined by recording the PMT output onto an oscilloscope.

The cells for LLNL are open ended celis, and provided the best jitter. Closed cells were also tested, and the jitter increased somewhat for these systems. The water level in the open and closed ended cells was at the level of the neck in the cells. We note that cells with cylindrical geometry can also be used, however, this specific geometry results in focusing of the emitted light, whereas with the spherical cells, the emitted light remains spherical, and is more easily collimated, or focused.

LLNL currently has one cell with the required output. APL has a similar cell, for use in diagnostics and confirmation of results.

Personnel:

Thomas J. Matula, Ph.D. acted as overall coordinator and scientist.

Dustin Froula, an undergraduate student, built levitation cells at LLNL and studied the jitter of various configurations. 


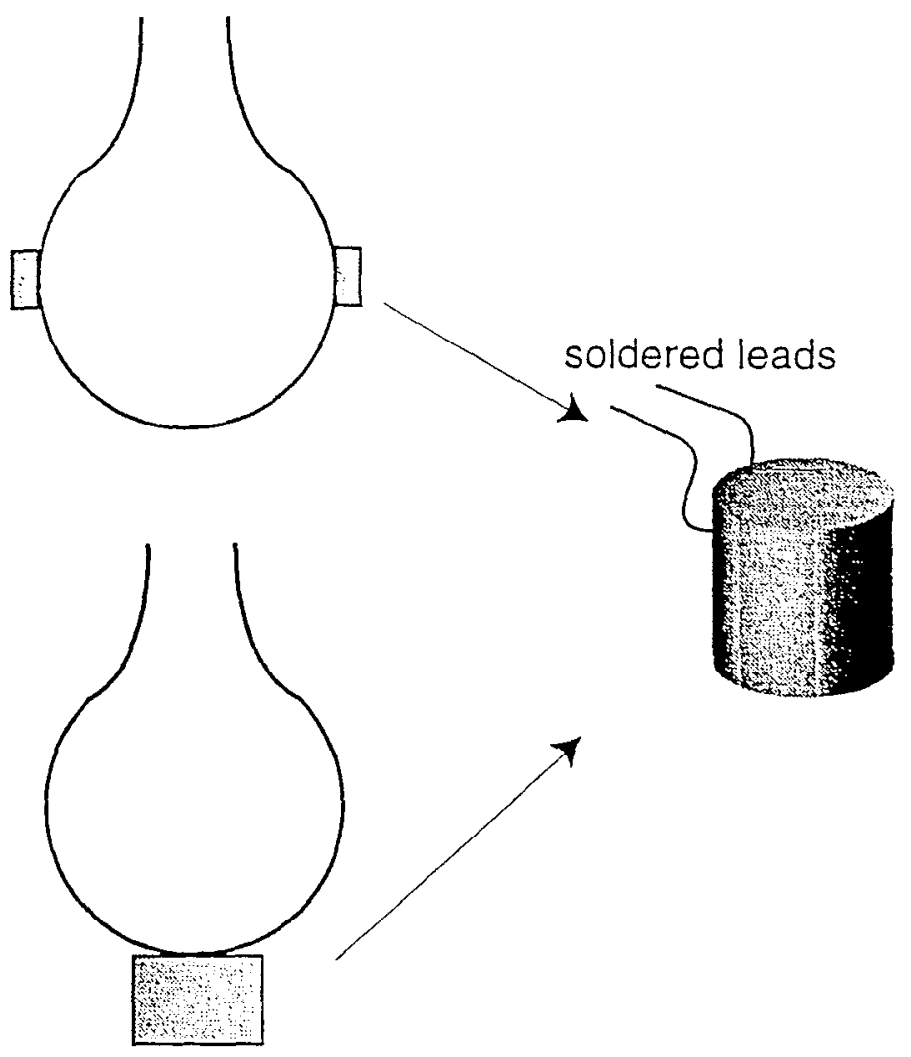

Figure 1: Diagram of PZT mounting configurations

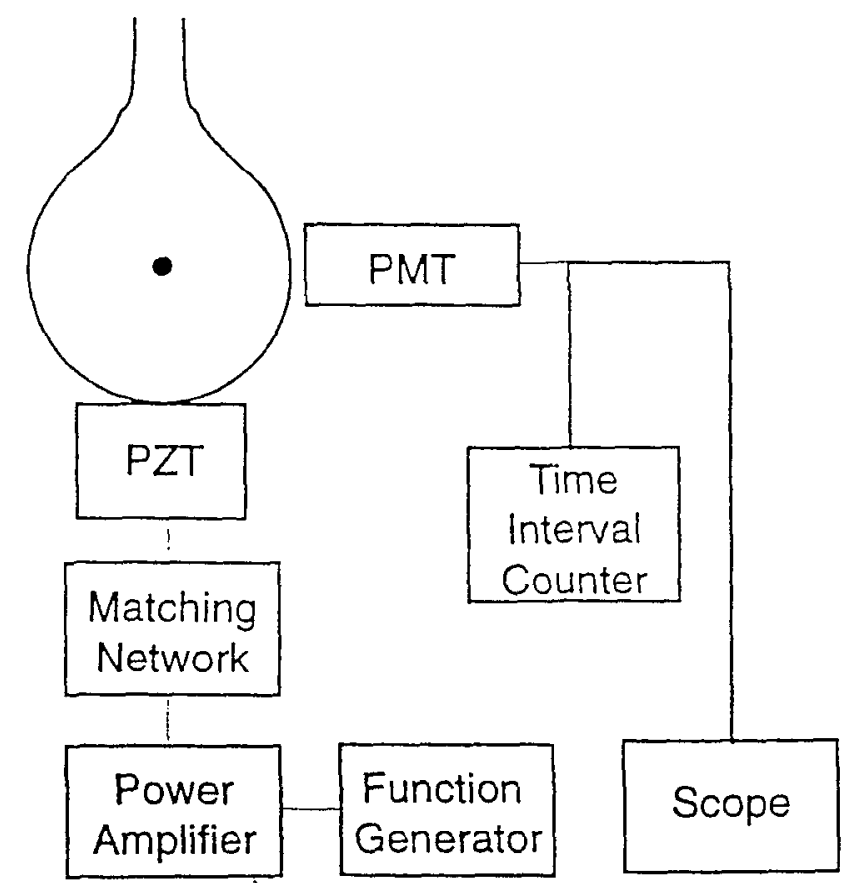

Figure 2. A schematic diagram of the SBSL apparatus used in jitter measurements. 


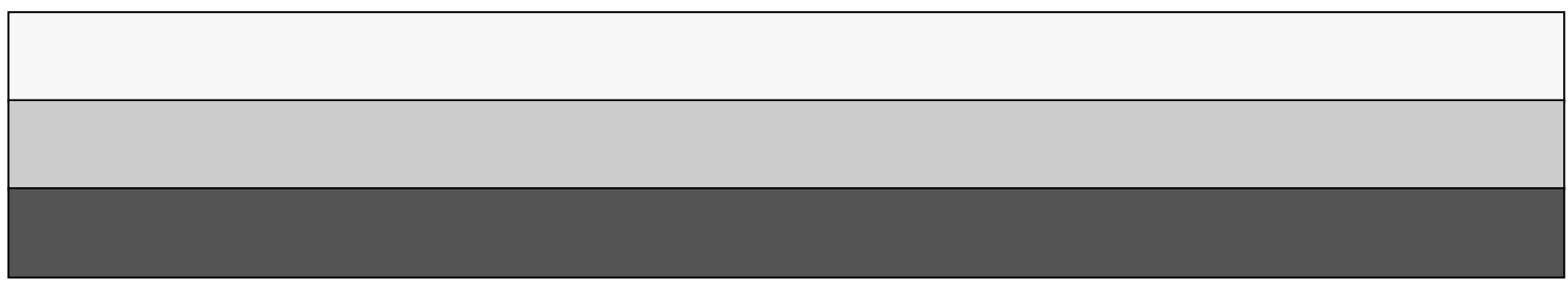

